\title{
Social media and adolescents: Possibilities for satisfying.psychological needs. Results of in-depth interviews with Russian pupils and university students ${ }^{1}$
}

\author{
Anna Tolokonnikova \\ Denis Dunas ${ }^{2}$ \\ Diana Kulchitskaya \\ Lomonosov Moscow State University, Russia
}

To cite this article: Tolokonnikova, A., Dunas, D., \& Kulchitskaya, D. (2020). Social media and adolescents: Possibilities for satisfying psychological needs. Results of in-depth interviews with Russian pupils and university students. World of Media. Journal of Russian Media and Journalism Studies 4: 37-56. DOI: 10.30547/worldofmedia.4.2020.2

\begin{abstract}
The article examines the possibilities for satisfying adolescents' basic psychological needs in a digital environment. The study is based on a series of in-depth interviews with youth representatives with profound knowledge of digital technologies that are strongly integrated into their daily routine (a total of 20 interviews). The sample group included school pupils and university students from Moscow, Rostovon-Don and Nizhny Novgorod aged from 10 to 19 (born in 1999-2008). According to the most common childhood periodization in Russia by Daniel Elkonin (1989), the chosen age range allows to fully cover the period of adolescence, as well as early juvenility. This simplifies the task of matching schoolchildren's motives when addressing the media with their basic psychological needs. The analysis of the collected data indicated that such basic needs of adolescents as desire to obtain knowledge, pursuit of communication and grouping with peers, interest to 'try on' various social roles, formation of one's identity, etc., today can be fully satisfied within the digital environment. This makes certain Internet resources (in particular, social networks and instant messengers) especially attractive to the young audience, as the main media and communication platforms for the modern youth.
\end{abstract}

${ }^{1}$ The research is supported by the grant of the Russian Science Foundation (project No.18-78-10090).

${ }^{2}$ Corresponding author:

Denis Dunas, Lomonosov Moscow State University, Faculty of Journalism,

9, Mokhovaya st, Moscow, Russia.

Email: dunas.denis@smi.msu.ru 


\section{Keywords}

Digital generation, digital youth, psychological needs, satisfaction of needs.

\section{Introduction}

Media practices today are fully integrated into the lives of modern children and adolescents. At the same time, the minimum age of entering the global network has lowered significantly in recent years. A study, conducted in 2013, states that Russian children begin to use the Internet actively when they are 8-9 years old, while the corresponding data of 2017 indicate that youngsters start going online in preschool age. According to the research, $80 \%$ of Russian children aged from four to six already use the Internet. ${ }^{3}$ Although the main online activities at such an early age include consumption of media content (cartoons, primarily) as well as video games, Russia finds itself among the most developed countries in terms of familiarizing children with the global network.

By the time they reach adolescence, technological innovations become so closely integrated into the life of school children that the virtual reality often becomes the environment where they grow up, learn and develop. A study conducted by MOMRI in October 2018 indicated that there are two key media resources for young people today - television and the Internet. ${ }^{4}$ Traditional television is regularly watched by $73 \%$ of children aged from 2 to 12, who also spend at least three hours a day on the Internet. ${ }^{5},{ }^{6}$ Moreover, as the child grows older, they go online more often and watch TV much less.

Being active users of social networks, young people mostly learn the news from there (Vartanov et al., 2016; Dunas et al., 2018). We can also witness a growing popularity of instant messengers among young people with an annual corresponding audience growth of $9 \%$. The most active users of messengers are those aged from 10 to 12 , representing $60 \%$ out of the total age group. This percentage corresponds with the estimates of children having a smartphone. However, only $47 \%$ of them use social networks. ${ }^{7}$

The available data on the structure and volume of media consumption make it possible to understand what resources are the most popular ones among

\footnotetext{
${ }^{3} 80 \%$ of children aged 4-6 In Russia use the Internet. Kommersant, $27^{\text {th }}$ February, 2017. Available from: https://www.kommersant.ru/doc/3227981

${ }^{4}$ Georgievskaya, M. Children's media consumption. What is interesting to a young audience on the Internet and on TV. Adindex, $18^{\text {th }}$ March, 2019. Available from: https://adindex.ru/news/researches/2019/03/17/270654.phtml

${ }^{5}$ The same source.

${ }^{6}$ According to Mediascope / TNS Web Index data, November, 2018.

${ }^{7}$ Georgievskaya, M. Specified source.
} 
young people, but they do not provide an answer to the question why young Russians choose certain media sources and what motivates them to use this or that media source (Kulchitskaya, 2019; Kulchitskaya et al., 2019; Filatkina \& Davletshina, 2019).

In research literature there have been various attempts to identify the motivations behind media use among teenagers. For example, Sonia Livingstone (2008) in a cross-method study showed that for adolescents the use of social media involves a balance between opportunities and risk. The opportunities are connected with identity-building, socializing and finding intimacy, while the risks are connected with privacy issues, potential misunderstanding and abuse. Scholars have also paid attention to the way different psychological variables of teenagers are associated with their intention to participate in a flash mob in social networks. A group of US researchers found that the higher was the selfefficacy of teenagers, the more likely they were to participate in a flash mob in social networks (Seo et al., 2014). The study also shows that the higher was the desire of a respondent 'to belong', the more time they were spending online.

Based on previous research and findings, the authors of this article presume that the virtual space today can satisfy certain adolescents' psychological needs that are specific to the respective stage of personality development, which makes the Internet environment especially attractive to them. In order to test this hypothesis, the following research tasks were formulated:

- summarize the available theoretical data regarding the adolescents' basic psychological needs;

- conduct in-depth interviews with schoolchildren and students born in 1999 and later, who represent the first 'digital generation' in Russia, in order to identify the features of media communication practices of young Russians and their motives for using various media resources;

- compare the obtained empirical data with the main theoretical thesis and understand what basic psychological needs of adolescents can be satisfied in the digital media environment today.

\section{Literature review and theoretical concepts}

The changes in the society functioning foundations and the formation of new types of cultures within a community (in particular, the digital media culture) are directly correlated with the changes in individual practices of media consumption. There are changes both in the motives of the audience's appeal to various types of media and in the factors that determine the shift of those (Courdry \& Hepp, 2016; Soldatova et al., 2017; Taneja et al., 2012; Vartanova, 
2019). The main theoretical approach in media research that considers the process of using media in the context of satisfying needs is the theory of uses and gratification (Katz, Blumler, \& Gurevitch, 1973; Katz, Gurevitch, \& Haas, 1973; Papacharissi \& Rubin, 2009; Ruggiero, 2000; Vartanova, 2014; Vincent \& Basil, 1997). This theory does not belong to a particular author as during the development of scientific knowledge the study has been referred to, elaborated and developed by various researchers. Today it is exposed to the dynamic changes due to its increased influence on all spheres of public and personal life through a new phenomenon of reality - the Internet environment, or virtual space, treated not just as a set of technologies, but as a habitat (Soldatova et al., 2017; Vartanova, 2001).

It is worth noting that the virtual space and the Internet in general are getting more frequently considered by psychologists not as a separately existing reality that can be observed from the outside, but as an integral part of everyday life (Nosov, 2000). According to Soldatova and Rasskazova, 'in relation to children and adolescents, we are talking about the space where they develop - metaphorically speaking, about the special "digital" situation of their development and socialization, where technologies are intertwined with life from an early age' (Soldatova \& Rasskazova, 2015, 2016, 2017). The close interconnection between media and children's games was underlined by Sonia Livingstone: 'There is a mutual re-negotiation of meaning - nonlinear, unpredictable - that alters the children, their play and the cultural meaning of the game itself. The media do not simply add a new element to the story, they transform it'; this allows us to speak of the phenomenon of the 'mediation of childhood' of childhood (Livingstone, 2009).

As a result of these media transformations, previously media-based needs turn into basic human needs, while the needs that could be met indirectly through the act of mediation can now be met directly as a result of the mediatization process, and the young people, being 'digital natives' (Prensky, 2001) of today's media audience most vividly embody the fundamental changes in media practices that transform theoretical knowledge: the classical uses and gratification theory gets reinterpreted when the media consumption practices of young people in the digital environment, especially in social networks, become a subject of analysis (Baek et al., 2011; Dunas et al., 2019; Kurzban et al., 2015; Lang \& Bradley, 2010; Lee \& Ma, 2012; Quan-Haase \& Young, 2010; Vartanova, 2015; Gladkova, 2017).

The boundaries of adolescence are somewhat blurred. The most common childhood periodization in Russia, which forms the basis for the entire system 
of country's preschool and school education, belongs to Daniel Elkonin (1989). The following age gradation is proposed:

1. Infancy: from birth to the age of 1 .

2. Early childhood: 1 to 3 -year-olds.

3. Young and middle preschool age: 3 to $4-5$-year-olds.

4. Senior preschool age: 4-5 to 6-7-year-olds.

5. Younger school age: 6-7 to 10-11-year-olds.

6. Adolescence: $10-11$ to 14-15-year-olds.

7. Early juvenility: 14-15 to 16-17-year-olds (Elkonin, 1989; Tkacheva \& Khilko, 2013).

According to the mentioned periodization, adolescence largely coincides with the time of study in secondary and high schools and, along with the early juvenility, covers the age period of children from the time they are 10-11 years old to 16-17 years.

We should note the existence of other approaches to the periodization of the childhood and adolescence stage. One of the leading researchers in this sphere is Lev Vygotsky, who defined different critical and 'calm' periods in the life of a child and an adolescent. The table below describes these stages as defined by Vygotsky (Vygotsky, 2013).

Table 1

Childhood and adolescence periodization (according to Lev Vygotsky)

\begin{tabular}{|c|c|c|}
\hline Period in life & Crisis & Duration of the period \\
\hline Infancy & Crisis at age 1 & $\begin{array}{c}\text { From } 2 \text { months } \\
\text { until 1 year }\end{array}$ \\
\hline Early childhood & Crisis at age 3 & From 1 until 3 \\
\hline Pre-school age & Crisis at age 7 & From 3 until 7 \\
\hline School age & Crisis at age 13 & From 7 until 13 \\
\hline Adolescent age & Crisis at age 17 & From 13 until 17 \\
\hline
\end{tabular}

Finally, another prominent approach to childhood periodization can be found in the works of Lidia Bozhovic, a famous Soviet psychologist. Her view of personality development is in some ways similar to the one used by Vygotsky and Elkonin. However, she saw the so-called inner position of personality as a driving force on different stages of personality development (Bozhovic, 1998).

Leading Russian specialists in the field of developmental psychology distinguish a range of needs that are typical for the teenage period (Elkonin, 
1989; Idobaeva et al., 2011; and others). There is an obvious increase in shifting the possibilities of satisfying many of those by the means of the virtual environment. In the context of media consumption research, the mentioned needs can be divided into several groups.

Firstly, there is the informational need of adolescents as well as their need for self-development. That is as the distinctive features of puberty are curiosity and inquisitiveness. A teenager seeks to acquire as much knowledge as possible, while the obtained information is not always directly related to his/her studies, as sometimes the adolescent is not yet able to systemize it clearly (Lobanova \& Muzychenko, 2012).

Secondly, these are needs associated with self-knowledge and selfidentification: the development of self-esteem, the desire to express one's identity, the formation on one's self-concept (Selishcheva, 2012). Typical for puberty expressions include experiments with identity, the desire to play various social roles and 'try on' different appearances (Kiryakova, 2017).

Thirdly, there is a need for communication with peers. The feeling of loneliness peculiar to this age gives rise to the need for friendly support (Kon, 1979; Krushelnitskaya, 2007). At the same time, the intimate personal communication generally becomes the leading activity that dominates at this stage of development (Elkonin, 1989).

During puberty, children get a lot of acquaintances, they tend to unite in informal communities. A desire to join a reference group (idioculture) is highly common for adolescents as they want to indulge in it, share their values with others and thus feel protected (Babaeva et al., 2000; Krushelnitskaya, 2008). In this case the desire to coexist among peers appears literally on the instinctive level, which makes psychologists talk about the 'peer grouping reaction' typical for adolescents - a concept introduced by the Soviet psychiatrist A. Lichko (1985).

One should consider the fact that in the conditions of modern urban civilization, some of the fundamental emotional needs of adolescents cannot always be satisfied in a natural way. Many children become 'hostages' of city apartments as they live in accordance with a clearly fixed schedule of basic and extracurricular classes. Therefore, very few teenagers have time and opportunity to pay attention to their real interests and needs or to meet friends as often as they would like. According to evolutionary psychology, this is the reason behind some of the adolescence problems as well as the teenage crisis, a notion well-known to all parents (Palmer J. \& Palmer L., 2007). At the same time, it can be assumed that we are witnessing the rise of new, technologically determined forms of satisfying age-related requests, where the Internet along with the social media essentially become the basis, and possibly the only medium that allows adolescents to 
solve psychological problems that are basic for their age: the need to broaden their horizons, communicate, search for the own identity as well as for an inner circle.

\section{Methods}

The study is based on a series of in-depth interviews with schoolchildren in the spring of 2019. The sample included youth representatives born from 1999 to 2008 aged from 10 to 19 years old. This age range allows us to fully cover the teenage period while also capturing the young people who have just entered their juvenility. The respondents were assigned to three groups in accordance with their stage of education:

- middle school students - aged from 10 to 15 years old (year of birth from 2004 to 2008),

- high school students - aged from 16 to 17 years old (year of birth from 2002 to 2003),

- university freshmen - aged from 17 to 19 years old (year of birth from 1999 to 2001).

Interviews were conducted with at least six representatives of each group (a total of 20 interviews). The authors did not deliberately seek to assign the participants into groups by gender and identify differences in their media consumption from this perspective, however, the number of each group's members turned out to be almost equally split by gender with nine young men and eleven girls providing their answers.

The selected respondents reside in Moscow, Rostov-on-Don and Nizhny Novgorod. The choice of cities was correlated with the object of study - youth representatives born in the years from 1999 to 2008 inclusive that are tech-savvy and whose daily lives are strongly associated with digital technologies. Based on the theory of generations, we assume that the 'digital youth' most effectively implements the ability to access digital technologies in cities with a population of over one million, where a developed system of information and communication networks has already been created. The three selected cities meet the indicated criteria: according to the Federal State Statistics Service data as of January 1, 2019, they were among the 15 Russian cities with population exceeding one million people and high rates of Internet penetration. ${ }^{8}$ In addition, all three cities possess a developed structure of higher educational institutions, which is

\footnotetext{
${ }^{8}$ Goroda millionniki Rossii 2020 [Cities with population of a million people and over in Russia 2020, 2019]. Statdata.ru, 30th January, 2020. Available from: http:// www.statdata.ru/goroda-millionniki-rossii-po-naseleniu
} 
an important factor for this research as respondents of the selected age group include junior university students.

The questions asked during the interview can be summarized in the following way:

1. Do you listen to the radio/watch TV/read newspapers/browse the web/ use social networks and messengers?

2. If you do watch TV/listen to the radio/read newspapers and magazines, why do you do it? If not, what are the reasons for avoiding this or that media platform?

3. In what circumstances do you turn to this or that content or a media platform?

4. For what purposes do you use social networks and messengers? What kind of content do you like to watch and why? What kind of content do you like to post online?

5. What kind of activities do you perform online?

Thus, the interviews were mostly focused on the motivations to use or not to use this or that content on a specific platform (TV, radio, print, online). The volume of media consumption was also taken into account, however the questions were mostly focused on 'why?' rather than 'how long?' For this particular paper we decided to focus our attention on social networks and messengers as the main communication platforms for contemporary teenagers, although our study covered both traditional and new media. This decision was defined by the results we got and by the general media consumption patterns of the young digital generation.

Undoubtedly, it can be assumed that the practice of media resources usage and the structure of media consumption varies depending on the region and therefore cities with population below one million people will demonstrate different characteristics due to a number of socio-economic factors. However, this research aims to study the segment of youth with the highest level of involvement in the digital environment and therefore to analyse precisely the leading practices. In addition, given the limited resources, studying Russian youth nationwide would be a very complex objective.

One should also note that this research was conducted as a pilot study, aiming to verify the hypothesis and develop a toolkit for further in-depth analysis - a large-scare sociological study, investigating the motives of adolescents' media consumption in the selected cities. 


\section{Results}

The study indicated that for the group of the survey's participants the virtual environment indeed provided broad opportunities for addressing the basic agerelated psychological needs. In this case, just as for adults, this was an evident satisfaction of the needs for new information and self-development. The Internet with its diverse news and educational resources, numerous lessons, webinars and master classes, responds to such requests of schoolchildren and students in the most convenient and affordable way. This was mentioned by almost all the study participants with the following statements in place: 'If something interests

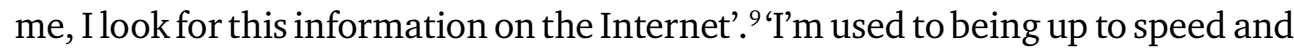
getting a lot of information quickly. ${ }^{10}$ 'For me, social networks are not just about communication, but also about the opportunity of getting new information'. '11 'If there is a topic about my hobby, something that interests me, I will make sure to find it on the Internet and take a look at it'. ${ }^{22}$ 'I look for different information online $\langle\ldots\rangle-$ depending on the day. If it is a day at school, then I will search for some education-related topics'. ${ }^{13}$ 'If a news story interests me, I will google it to learn more about it'..$^{14}$ 'I look for the information related to my studies, for scientific facts'. ${ }^{15}$ 'Still, the Internet today is probably the fastest access provider for any information you need'. ${ }^{16}$

It is noteworthy that many of the study participants mentioned that they usually look for the information regarding their topic of interest using several sources at once, collecting their final vision of a topic as a puzzle: 'If the news story is interesting, I look for some information about it on several web-sites

\footnotetext{
${ }^{9}$ Respondent 3. City: Moscow. Gender: female. Age: 17. Status: university student, $1^{\text {st }}$ year.

${ }^{10}$ Respondent 1. City: Moscow. Gender: male. Age: 18. Status: university student, $1^{\text {st }}$ year.

${ }^{11}$ Respondent 3. City: Moscow. Gender: female. Age: 17. Status: university student, $1^{\text {st }}$ year.

${ }^{12}$ Respondent 16. City: Rostov-on-don. Gender: male. Age: 13. Status: school student, $7^{\text {th }}$ grade.

${ }^{13}$ Respondent 9. City: Nizhny Novgorod. Gender: female. Age: 17. Status: school student, $11^{\text {th }}$ grade.

${ }^{14}$ Respondent 11. Nizhny Novgorod. Gender: male. Age: 14. Status: school student, $7^{\text {th }}$ grade.

${ }^{15}$ Respondent 18. City: Rostov-on-don. Gender: female. Age: 16. Status: school student, $9^{\text {th }}$ grade.

${ }^{16}$ Respondent 13. Nizhny Novgorod. Gender: male. Age: 17. Status: school student, $11^{\text {th }}$ grade.
} 
instead of just one to get the most complete picture of what is going on'. ${ }^{17}$ 'I like to compare the information and look through different web-sites, especially when it comes to studying. This way I get the big picture'. ${ }^{18}$

Young people also stated that they often immediately verify the authenticity of the information they are interested in and do not trust everything right away: 'If I see something that is very serious news, I will try to check it using different sources'. ${ }^{19}$ 'After someone tells me something, I address the Internet to make sure it is true'. 20 'When a video is included, I go to "search by image" on Yandex, attach a screenshot of this video $<\ldots>-$ I check whether it is true or not'. ${ }^{21}$

Another interesting feature identified in the process of analysing the interviews was that adolescents consume the news not only to obtain new information, but, sometimes, exclusively for communication purposes - in order to be able to later discuss the news with friends: '[I read news on the Internet authors' note], firstly, for myself, and secondly, to avoid being "ignorant" when my friends talk, to quickly join the conversation'. ${ }^{22}$ 'Some of the current agenda interests me, I like to keep up with the conversation, and I do not like to be in a situation when people are aware of something and they start to discuss it while I do not understand what they are talking about, because I do not know any news'. ${ }^{23}$ 'Even news that interests me, I would first learn it from my friends'. ${ }^{24}$ Thus, we can observe within the nature of the 'digital generation' representatives how the consumption of information becomes one of the fundamentals of personal and social experience - a certain unity of 'media' and 'social' characteristics that are specific for the definition of the idea of a human being as 'homo mediatis', according to E. Vartanova (2013).

${ }^{17}$ Respondent 1. City: Moscow. Gender: male. Age: 18. Status: university student, $1^{\text {st }}$ year.

${ }^{18}$ Respondent 3. City: Moscow. Gender: female. Age: 17. Status: university student, $1^{\text {st }}$ year.

${ }^{19}$ Respondent 2. City: Moscow. Gender: male. Age: 16. Status: school student, $10^{\text {th }}$ grade.

${ }^{20}$ Respondent 15. City: Rostov-on-don. Gender: female. Age: 15. Status: school student, $9^{\text {th }}$ grade.

${ }^{21}$ Respondent 16. City: Rostov-on-don. Gender: male. Age: 13. Status: school student, $7^{\text {th }}$ grade.

${ }^{22}$ Respondent 7. City: Moscow. Gender: male. Age: 12. Status: school student, $6^{\text {th }}$ grade.

${ }^{23}$ Respondent 5. City: Moscow. Gender: female. Age: 16. Status: university student, $1^{\text {st }}$ year.

${ }^{24}$ Respondent 11. Nizhny Novgorod. Gender: male. Age: 14. Status: school student, $7^{\text {th }}$ grade. 
Almost all the interviewed schoolchildren and students prioritize the communication capabilities of the Internet. 'For me, it is important [to have access to the Internet-authors' note] to know what is going on with my friends' ${ }^{25}$ 'There are not only videos and pictures on the Internet - my chats are there!' ${ }^{26}$ 'It is important for me to have access to communication with people'. ${ }^{27}$ 'Social networks and the Internet $\langle\ldots\rangle$ put everything together, and it is done very conveniently. That allows me to listen to music and communicate with friends at the same placein a quick manner, as if they were next to me'. ${ }^{28}$ 'I keep in touch with friends through various messengers $\langle\ldots\rangle$, I also learn the news from social networks quite often'. ${ }^{29}$ 'Communication goes mainly through the Internet. It is not as much important as it is practical, convenient'. ${ }^{30}$ 'I create and post something in order to share my story, so that people - my acquaintances, friends, see it and we discuss it somehow. Perhaps they will advise me on something, ${ }^{31}$ - the respondents declare.

Mostoftheintervieweesindicated thattheynaturallycontinuetocommunicate within the digital environment with whom they constantly communicate in real life: 'There are people I meet every day, but once the evening comes, I already start writing them. We continue to communicate again - via the Internet' ${ }^{32}$ However, social media today allow students to expand their social circle even when they are outcasts among classmates and do not have any steady friends within their close environment: '[Internet - authors' note] allows me to communicate with friends, even if they are far away, even if they do not live in my city'33; 'There

${ }^{25}$ Respondent 7. City: Moscow. Gender: male. Age: 12. Status: school student, $6^{\text {th }}$ grade.

${ }^{26}$ Respondent 11 . Nizhny Novgorod. Gender: male. Age: 14. Status: school student, $7^{\text {th }}$ grade.

${ }^{27}$ Respondent 14. Nizhny Novgorod. Gender: female. Age: 15. Status: student of school, $9^{\text {th }}$ grade.

${ }^{28}$ Respondent 2. City: Moscow. Gender: male. Age: 16. Status: school student, $10^{\text {th }}$ grade.

${ }^{29}$ Respondent 6. City: Moscow. Gender: female. Age: 16. Status: school student, $10^{\text {th }}$ grade.

${ }^{30}$ Respondent 17. City: Rostov-on-don. Gender: female. Age: 19. Status: university student, $2^{\text {nd }}$ year.

${ }^{31}$ Respondent 5. City: Moscow. Gender: female. Age: 16. Status: university student, $1^{\text {st }}$ year.

${ }^{32}$ Respondent 4. City: Moscow. Gender: male. Age: 17. Status: school student, $11^{\text {th }}$ grade.

${ }^{33}$ Respondent 14. Nizhny Novgorod. Gender: female. Age: 15 . Status: school student, $9^{\text {th }}$ grade. 
are virtual friends with whom I communicate because they come from other countries'. ${ }^{34}$

The anonymity and lack of regulations behind the Internet communication in general makes it easier for adolescents compared to personal communication: 'In real life there are topics you cannot explain or discuss, while you can write about it on the Internet... It is easier to say something on the Internet than in real life.'. ${ }^{35}$ Another statement on this subject: 'Many have started writing serious things on social networks, messengers and things you can mention while looking at the screen of your phone or computer you cannot say to a person's face. It is very different'. ${ }^{36}$

Thus, the satisfaction of the psychological need for intimate personal communication, which, as noted above, is the leading activity at this stage of development, is largely shifted to the Internet environment today and can be fulfilled by the means of digital resources.

In this context, the conclusion of A. Gretsov, who studied adolescents' modern friendship ideas, seems especially interesting. According to the researcher, friendship between teenagers going through puberty today changes not from the goals perspective, but from the perspective of communication tools and approaches to the time structuring: the share of communication between friends, mediated by the modern technical means, is growing - such as correspondence by e-mail or within online communities, mobile phone conversations, etc. At the same time, the goals of friendship remain unchanged - same as before 20, 30 years ago: those include emotional support, mutual understanding and assistance (Gretsov, 2005).

The strongly pronounced desire of modern teens to be a part of informal groups of peers, distinctive for this age (Krushelnitskaya, 2007), to join a community of like-minded individuals and to share own values and beliefs with them, can be satisfied by the means of the network resources today. The interviewed youngsters were members of many online communities, where they communicated both with their real and virtual friends. In fact, groups in messengers and social networks today play the role of subcultural platforms that have always attracted the younger generation. Perhaps this is the reason why the representatives of this age group are the most active users of social media.

${ }^{34}$ Respondent 16. City: Rostov-on-don. Gender: male. Age: 13. Status: school student, $7^{\text {th }}$ grade.

${ }^{35}$ Respondent 4. City: Moscow. Gender: male. Age: 17. Status: school student, $11^{\text {th }}$ grade.

${ }^{36}$ Respondent 5. City: Moscow. Gender: female. Age: 16. Status: university student, $1^{\text {st }}$ year. 
Moreover, the interest in social networks can be attributed to the fact that such resources offer a field for experiments with self-presentation, allowing users to build their own virtual personality in different ways (Kiryakova, 2017). 'Social networks $\langle\ldots\rangle$ always create a pronounced virtual image of the user, regardless of whether you chat with this person or just look at their page', ${ }^{37}$ according to one of the respondents.

Tools that allow to hide real characteristics and appearance, while creating own 'virtual Self' and endowing it with desired qualities were actively used by both study participants and their peers when it came to the social networks' posts. 'My photos and I are two different people, and I am very confused that everyone now has an opinion about a person based on social networks and photos posted there. Often those are completely different people', ${ }^{38}$ the interviewee mentioned.

Indeed: it is as if messengers and social networks allowed children of puberty age to 'try on' various 'masks', master new social roles and behaviours.

Observing the adolescents' social media accounts made authors note that some of the teenagers deliberately seek to create a 'grown-up' image in their photographs. Others tend to use images of their favourite animated characters, photographs of actors, athletes or show business stars as their profile picture instead of their own portrait. The others act natural, while transmitting everything that happens to them in everyday life in detail, trying to keep their real and virtual 'images' together: 'I am not trying to show myself as someone I am not. People look at pictures, photos... Not just my friends, but strangers as well. And I did everything I could, so they would not think I show myself differently'. ${ }^{39}$ 'I treat Instagram and maintaining a page there as an opportunity to share a piece of one's own life and things you love, not what others want to see in you. With this, I believe that a person should publish exactly what interests him/her...' 40 'For me, likes are not an indicator. I post something to share it with friends. I will not personally approach everyone and show each person: "Look, look at this photo!"41

${ }^{37}$ Respondent 6. City: Moscow. Gender: female. Age: 16. Status: school student, $10^{\text {th }}$ grade.

${ }^{38}$ Respondent 3. City: Moscow. Gender: female. Age: 17. Status: university student, $1^{\text {st }}$ year.

${ }^{39}$ Respondent 4. City: Moscow. Gender: male. Age: 17. Status: school student, $11^{\text {th }}$ grade.

${ }^{40}$ Respondent 5. City: Moscow. Gender: female. Age: 16. Status: university student, $1^{\text {st }}$ year.

${ }^{41}$ Respondent 16. City: Rostov-on-don. Gender: male. Age: 13. Status: school student, $7^{\text {th }}$ grade. 
We managed to trace some differences in the use of social networks between boys and girls, as well as between the capital and the regional cities. In Moscow the number of respondents who use their social media accounts to create content was higher than in the answers of the respondents leaving in the regions. We may try to explain this fact that in the capital the youngsters are exposed to the consumer culture at higher degree than young people living in regional metropolitan areas.

Another interesting finding proves that today a smartphone for most teenagers and young people is a means of identity-building and device, containing a lot of private content, which they would not always like to share with their parents. The respondents realize the risks associated with self-actualization in social networks, however, their level of awareness is different in different cases. The older teenagers get, the more concerned about privacy issues they become.

Various experiments with self-representation on the Internet become a certain psychological training for a teenager, helping them find their own self and personality, develop self-esteem (Babaeva et al., 2000; Baranova, 2012). All of the above refers to important psychological needs that are typical for this period of personality formation and are directly related to adolescents' basic age-related needs.

\section{Discussion}

The socio-cultural changes in contemporary Russian society are getting more evident than ever. These changes are especially visible when it comes to young people, as their everyday life and media consumption have been transformed tremendously. The current transformations are provoked by deep and wide integration of digital media technologies and media communication practices into the everyday life of young people.

Young Russians prefer digital media as the main source of information about the country and the world, they significantly limit the time of TV watching and reading print newspapers. For them, social networks have become a key communication platform, which forms the knowledge and the experience of the youth. The use of digital media has produced individual as well as social consequences for the audience. These consequences might cause new effects on the social life of separate communities and society as a whole. These effects are not entirely comprehended and studied yet.

In many respects the Russian digital youths are similar to European youngsters, for example. A big study of media use patterns among respondents 
in nine EU countries done by a group of researchers from Portugal shows that social networks are one of the dominant platforms among the age group studied (Pacheco et al., 2017). However, as the researchers from Lisbon note, old media still play a role in the media use of the young audiences, although the volume of time devoted to reading newspapers and watching TV is much smaller in comparison to the time spent online. This doesn't correlate with our results, which show that respondents in the three selected cities almost do not read print newspapers and watch TV only for entertainment purposes. Partly, these differences may be explained by the fact that in the study devoted to European states the age group is different (14-30) and includes youngsters in their 20s, a period, when young people become older and may need more serious content, which they can get in traditional media.

Digital media, and especially social media, are characterized by the power to build a new type of culture as a specific social and cultural system, and this transforms the media users' practices at all stages - from consumption towards production, perception, and finally to social action. Apparently, it becomes increasingly difficult to define the media needs of the 'digital youth'. The contemporary media use to a great extent is determined not only by the consumption of news information, knowledge, and entertainment, but also by the satisfaction of the needs related to the socio-cultural nature of individuals. The reasons for media use are associated with the need for affection and involvement in social and cultural communities, approval and integration into a newly emerging type of digital culture in society, influenced by technological development.

Digital media have the qualitative characteristics of a social sphere and cultural space. As a result, the needs and motives of the media audience are modified and are becoming socially and culturally determined.

Digital media today have formed an alternative virtual world, which overlaps with the real one, but at the same time dictates some new specific rules. To live in this world, one needs a device and access to the Internet. As many researchers note, for the youth their digital devices are not just tools, but in some way 'extensions of the self'. The smartphones have received an ontological meaning for young people and in many ways help them show their identity to others. The development of the digital world shows that there are two dimensions, where people can satisfy their needs - the physical world and the virtual one.

The study showed that young people do not draw a distinctive line between the real and the virtual worlds. Thus, the last one becomes not a substitute for the real one but its extension. 


\section{Conclusion}

The authors' assumption that virtual space today is especially attractive for adolescents as it allows them to satisfy certain age-related psychological needs, has been generally proven.

Based on the analysis of theoretical works devoted to the puberty studies, a number of basic psychological needs that are typical to this particular stage of personality formation have been identified. The list included: 1) a strive for knowledge and self-development, a desire to broaden one's own horizons, to gain new information 2) a desire to 'try on' various social roles, find one's own identity, self-identification and formation of a 'self-concept'; 3) a desire to manifest own individuality and development of self-esteem; 4) a need for communication, especially, for an intimate personal one; 5 ) the need for grouping with peers.

Interviews with 20 respondents from Moscow, Nizhny Novgorod and Rostov-on-Don indicated that the satisfaction of the majority of the mentioned needs for the participants of the study today has indeed shifted to the digital environment, not only due to the fact that the Internet, instant messengers and social networks become their 'natural habitat' and represent a significant part of everyday life, but also because they appear as a door to the endless opportunities to fulfil their desires.

It can also be assumed that in the conditions of modern urban realities, the Internet and the social media become the main, and sometimes the only opportunity to fulfil adolescents' basic needs. At the same time, the problems, solutions for which have shifted towards the virtual environment today, essentially remain the same - those are obtaining new information, selfdevelopment, searching for one's own self and a like-minded circle.

We suggest that this is precisely what brings the attention of the young audience to such resources, turning theminto the main media and communication platforms for the generation of 'digital' Russians.

This allows us to confirm the formulated hypothesis and suggest its verification in the framework of further, larger-scale sociological studies aimed to investigate the psychological motives of adolescents' turn to network media resources.

\section{References}

BABAEVA, YU. D., VOJSKUNSKIJ, A. E., \& SMYSLOVA, O. V. (2000). Internet: Vozdejstvie na lichnost' [Internet: Impact on the person] In: A. E. Vojskunskij, Gumanitarnye issledovaniya $v$ Internete [Humanitarian research on the Internet], 
Mozhaisk, Mozhajsk-Terra, pp. 11-39. Available from: http://www.relarn.ru/ human/pers.html

BAEK, K., HOLTON, A., HARP, D., \& YASCHUR, C. (2011). The links that bind: Uncovering novel motivations for linking on Facebook. Computers in Human Behavior, 27(6), pp. 2243-2248. DOI: 10.1016/j.chb.2011.07.003

BARANOVA, YU. M. (2012). Obshchenie podrostkov v social'nyh internetsetyah kak osobyj vid kommunikacii [Communication of teenagers in social Internet networks as a special type of communication]. Nauchnye Problemy Gumanitarnyh Issledovanij, 4, pp. 105-110.

BOZHOVIC, L. I. (2004). Developmental phases of personality formation in childhood (I). Journal of Russian \& East European Psychology, 42(4), pp. 35-54. Available from: https://doi.org/10.1080/10610405.2004.11059224

COULDRY, N. \& HEPP, A. (2016). The mediated construction of reality. Cambridge, Polity.

DUNAS, D. V., TOLOKONNIKOVA, A. V., \& CHEREVKO, T. S. (2018). Nablyudenie za potrebleniem informacionnogo kontenta studentami fakul'teta zhurnalistiki MGU [Monitoring the consumption of information content by students of the Faculty of Journalism of Moscow State University]. Mediascope, 4. DOI: 10.30547/ mediascope.4.2018.1

DUNAS, D. V., VARTANOV, S. A., KULCHICKAYA, D. YU., SALIKHOVA, E. A., \& TOLOKONNIKOVA, A. V. (2019). Teoreticheskie aspekty izucheniya mediapotrebleniya rossijskoj molodezhi: $\mathrm{K}$ peresmotru teorii ispol'zovaniya i udovletvoreniya [Theoretical aspects of studying the media consumption of Russian youth: Revising the theory of uses and gratification]. Vestnik Moskovskogo Universiteta. Seriya 10. Zhurnalistika, 2, pp. 3-28. DOI: 10.30547/vestnik. journ.2.2019.328

ELKONIN, D. B. (1989). Izbrannye psihologicheskie trudy [Selected psychological works]. Moscow, Pedagogika. Available from: http://psychlib.ru/ mgppu/eit/EIT-001-.HTM\#\$p1

FILATKINA, G. S. \& DAVLETSHINA, M. I. (2019). Mediapotreblenie molodezhi: Teoreticheskij obzor issledovanij (na primere Ispanii, Brazilii, Argentiny i Meksiki) [Youth media consumption: A theoretical survey of research (case study from Spain, Brazil, Argentina, and Mexico)]. MediaAlmanah, 3, pp. 95-103.

GLADKOVA, A. A. (2017). Psychological and socio-cultural adaptation of international journalism students in Russia: The role of communication skills in adaptation process. Psychology in Russia: State of the Art, 4(10), pp. 45-59.

GRECOV, A. G. (2005). Emocional'nye otnosheniya podrostkov so sverstnikami [Emotional relationships of adolescents with peers]. In: L. A. Regush, Psihologiya 
sovremennogo podrostka [Psychology of a modern adolescent], Saint Petersburg, pp. 62-73.

IDOBAEVA, O. A., KARABANOVA, O. A., PODOLSKIJ, A. I., \& HEJMANS, P. (2011). Psihoehmocional'noe blagopoluchie sovremennyh podrostkov i resursy ego povysheniya: Opyt mezhdunarodnogo issledovaniya [Psycho-emotional wellbeing of modern adolescents and resources for its improvement: The experience of international research]. Vestnik Moskovskogo universiteta. Seriya 14. Psychology, 2, pp. 10-21.

KATZ, E., BLUMLER, J. G., \& GUREVITCH, M. (1973). Uses and gratifications research. Public Opinion Quarterly, 37(4), pp. 509-523.

KATZ, E., GUREVITCH, M., \& HAAS, H. (1973). On the use of the mass media for important things. American Sociological Review, 38(2), pp. 164-181.

KIRYAKOVA, N. A. (2017). Vliyanie social'nyh setej na razvitie kommunikativnyh sposobnostej podrostkov [The impact of social networks on the development of adolescents' communication skills]. Koncept, 29, pp. 161-168. Available from: http://e-koncept.ru/2017/770833.htm.

KON, I. S. (1979). Psihologiya yunosheskogo vozrasta (problemy formirovaniya lichnosti) [Psychology of adolescence age problems of personality formation: a textbook]. Moscow, Prosveshchenie.

KRUSHELNICKAYA, O. B. (2007). Podrostok v sisteme referentnyh otnoshenij [The teenager in the system of reference relations]. Moscow, MPSI.

KULCHICKAYA, D. YU. (2019). Specifika mediapotrebleniya v vostochnoj i yugovostochnoj Azii [Media specificity in East and Southeast Asia]. MediaAlmanah, 1, pp. 140-147.

KULCHICKAYA, D. YU., VARTANOV, S. A., DUNAS, D. V., SALIKHOVA, E. A., \& TOLOKONNIKOVA, A. V. (2019). Mediapotreblenie molodezhi: Specifika metodologii issledovaniya [Youth media consumption: Specificity of research methodology]. Mediascope, 1. DOI: 10.30547/mediascope.1.2019.9. Available from: http://www.mediascope.ru/2529

KURZBAN, R., BURTON-CHELLEW, M. N., \& WEST, S. A. (2015). The evolution of altruism in humans. Annual Review of Psychology, 66, pp. 575-599. DOI: 10.1146/annurev-psych-010814-015355

LANG, P. J. \& BRADLEY, M. M. (2010). Emotion and the motivational brain. Biological Psychology, 84(3), pp. 437-450. DOI: 10.1016/j.biopsycho.2009.10.007

LEE, C. S. \& MA, L. (2012). News sharing in social media: The effect of gratifications and prior experience. Computers in Human Behavior, 28(2), pp. 331339. DOI: $10.1016 /$ j.chb.2011.10.002 
LICHKO, A. E. (1985). Podrostkovaya psihiatriya (Rukovodstvo dlya vrachej) [Adolescent psychiatry (A guide for doctors)]. Leningrad, Medicina. Available from: https://www.gumer.info/bibliotek_Buks/Pedagog/hrestomatia/59.php

LIVINGSTONE, S. (2009). On the mediation of everything: ICA Presidential address 2008. Journal of Communication, 59(1), pp. 1-18.

LOBANOVA, A. V. \& MUZYCHENKO, L. S. (2012). Izuchenie faktorov, obespechivayushchih psihologicheskuyu bezopasnost' lichnosti podrostkov [The study of factors that ensure the psychological safety of the personality of adolescents]. Izvestiya TulGU. Gumanitarnye Nauki, 2, pp. 336-347.

NOSOV, N. A. (2000). Virtual'naya psihologiya [Virtual psychology]. In: Trudy Laboratorii Virtualistiki [Works of Virtualistic Laboratory], Moscow, Agraf.

Ot teorii zhurnalistiki k teorii media. Dinamika mediaissledovanij v sovremennoj Rossii [From journalism theory to media theory. The dynamics of media research in modern Russia] (2019). Moscow, MSU Faculty of Journalism, 2019.

PACHECO, L., TORRES DA SILVA, M., BRITES, M. J., HENRIQUES, S., \& DAM SIO, M. J. (2017). Patterns of European youngsters' daily use of media. Observatorio (OBS*), 11(4). Available from: http://www.scielo.mec.pt/scielo.php?script=sci arttext\&pid $=$ S1646-59542017000400001\&lng $=$ pt\&tlng $=$ en.

PALMER,J.\&PALMERL. (2007).Evolyucionnayapsihologiya. Sekretypovedeniya Homo sapiens [Evolutionary psychology. Secrets of Homo sapiens behavior]. Saint Petersburg, Prajm-Evroznak. Available from: https://batrachos.com/sites/ default/files/pictures/Books/Palmer_Palmer_2003_E\%60volyutsionnaya\%20 psihologiya_Sekrety\%60\%20povedeniya\%20Homo\%20sapiens.pdf

PAPACHARISSI, Z. \& RUBIN, A. M. (2000). Predictors of Internet use. Journal of Broadcasting \& Electronic Media, 44(2), pp. 175-196. DOI: 10.1207/ s15506878jobem4402_2

PRENSKY, M. (2001). Digital natives, digital immigrants. Part 1. On the Horizon, 9(5), pp. 1-6.

QUAN-HAASE, A. \& YOUNG, A. (2010). Uses and gratifications of social media: A comparison of Facebook and instant messaging. Bulletin of Science, Technology \& Society, 30, pp. 350-361. DOI: 10.1177/0270467610380009.

RUGGIERO, T. E. (2000). Uses and gratifications theory in the 21st century. Mass Communication \& Society, 3(1), pp. 3-37.

SELISHCHEVA, YU. S. (2012). Obshchenie v Internete kak faktor socializacii i razvitiya podrostka [Communication on the Internet as a factor of socialization and development of a teenager]. Vestnik Sovremennogo Obrazovaniya, 5, pp. 180-182. Available from: http://sociosphera.com/files/conference/2012/k-27-9-12.pdf 
SOLDATOVA, G. U. \& RASSKAZOVA, E. I. (2015). Modeli peredachi opyta mezhdu pokoleniyami pri osvoenii i ispol'zovanii Interneta [Intergenerational transfer models for learning and using the Internet]. Voprosy Psihologii, 2, pp. 5667. Available from: https://elibrary.ru/item.asp?id $=25470006$

SOLDATOVA, G. U. \& RASSKAZOVA, E. I. (2016). Modeli cifrovoj kompetentnosti i deyatel'nost' rossijskih podrostkov onlajn [Digital competence models and online activities of Russian teenagers]. Nacionalnyj Psihologicheskij Zhurnal, 2(22), pp. 50-60.

SOLDATOVA, G. U. \& RASSKAZOVA, E. I. (2017). 'Cifrovaya' situaciya razvitiya mezhpokolencheskih otnoshenij: Razryv i vzaimodejstvie mezhdu podrostkami i roditelyami v Internete [The 'digital' situation of intergenerational relations: The gap and interaction between adolescents and parents on the Internet]. Mir Psihologii, 1, pp. 134-143.

SOLDATOVA, G. U., RASSKAZOVA, YE. I., \& NESTIK, T. A. (2017). Tsifrovoye pokoleniye Rossii: Kompetentnost' i bezopasnost' [The digital generation of Russia: Competence and security]. Moscow, Smysl.

TANEJA, H., WEBSTER, J. G., MALTHOUSE, E. C., \& KSIAZEK, T. B. (2012). Media consumption across platforms: Identifying user-defined repertoires. New Media \& Society, 14(6), pp. 951-968. DOI: 10.1177/1461444811436146

TKACHEVA, M. S. \& HILKO M. E. (2013). Vozrastnaya psihologiya: Konspekt lekcij [Developmental psychology: Lecture notes]. Moscow, YUrajt.

VARTANOV, S. A., GUREEVA, A. N., DUNAS, D. V., \& TKACHEVA, N. V. (2016). $\mathrm{K}$ voprosu o teoreticheskom ponimanii novostej $\mathrm{v}$ cifrovuyu ehpohu: transformaciya struktury, sil vliyaniya, zhiznennogo cikla [To the question of the theoretical understanding of news in the digital age: The transformation of structure, forces of influence, life cycle]. Vestnik Moskovskogo Universiteta. Seriya 10. Zhurnalistika, 3, pp. 3-16.

VARTANOVA, E. L. (2001). Novye problemy i novye prioritety cifrovoj epohi [New challenges and new priorities for the digital age]. Informacionnoe Obshchestvo, 3.

VARTANOVA, E. L. (2013). The media and the individual: Economic and psychological interrelations. Psychology in Russia: State of the Art, 6(1), pp. 110-118.

Vartanova, E. L. (2014). Postsovetskie transformacii rossijskih SMI i zhurnalistiki. [Post-Soviet transformations of Russian media and journalism]. Moscow, MediaMir.

VARTANOVA, E. L. (2015). Sovremennye rossijskie issledovaniya SMI: Obnovlenie teoreticheskih podhodov [Modern Russian media studies: Updating theoretical approaches]. Vestnik Moskovskogo universiteta. Series 10: Zhurnalistika, 6, pp. 5-26.

VINCENT, R. C. \& BASIL, M. D. (1997). College students' news gratifications, media use, and current events knowledge. Journal of Broadcasting \& Electronic Media, 41(3), pp. 380-392. 